\title{
Towards the Revitalization of Egyptian Nile Cruises: Opportunities and Challenges
}

\begin{abstract}
Nahla Mohamed Helmy
Hotel Management Department, Faculty of Tourism and Hotel Management, Beni Suef University, Egypt

\author{
Khaled Soliman Abd Elhalem \\ Tourism Studies Department, \\ Faculty of Tourism and Hotels, \\ Luxor University, Egypt
}

\begin{tabular}{l}
\hline ARTICLE INFO \\
\hline Keywords: \\
Cruises; Floating; \\
CORONA; \\
Opportunities; \\
Challenges. \\
\\
(JAAUTH) \\
Vol. 20, No. 1, \\
(2021), \\
PP. 145-174.
\end{tabular}

\section{Abstract}

Cruises are currently regarded internationally as arising tourism activities and the Nile Cruises have become one of the important components of the Egyptian tourism sector. The research is aiming at providing an overall and current profile of the Egyptian Nile Cruises as well as demonstrating the opportunities for, and challenges against the Egyptian Nile Cruises' revitalization. A questionnaire has been distributed among 35 managers of sampled floating hotels to illustrate the latest condition of the Nile Cruises. An interview has also been conducted to explore the opportunities, challenges, and visions for Egyptian Nile Cruises' development. It has been concluded that most of Egyptian Nile Cruises have been negatively affected by the sequences of critical crises that led to work stagnation and a decrease in profitability. Recently, there is an undesirable influence of the COVID-19 outbreak on Nile Cruises since the cruise ship is the first hospitality establishment adversely influenced by epidemics. However, Cruise trips are still a potential tourism field in Egypt as Upper Egypt is a unique tourist destination that surely guarantees tourists' demand. Finally, it is proposed to adopt modern marketing tools to attract new market segmentation and sign protocols with inspection companies to control the health and safety as well as manage the anti-virus infection and protection procedures.
\end{abstract}

\section{Introduction}

Although oceans and rivers have been utilized as a means for transport, oceans and rivers' cruising has been emerged as entertainment activity by the late 1960s and early 1970s. Cruising developed gradually during the 1970s and 1980s. However, after 10 years, cruising has immediately become an active place for entertainment and played an important role in the leisure tourism market. Consequently, cruising has upgraded its product and service offer to the extent that it has become an arising trend in the tourism market (Jones, 2016). Current cruise ships have become a small model of the tourism industry, merging all fields of the industry, including transport, lodging, food and drinks 
service, sightseeing, and tour organization (Whyte et al., 2018). This kind of tourism has become very common, involving many world destinations, the fact that has achieved remarkable growth. All forecasts categorize cruise tourism as the best current and prospective type of tourism. Therefore, many destinations measured their tourism growth with the development of cruise ship activities (Garay et al., 2014). The cruise field is the rapidly developing part of the tourism sector. The annual growth ratio in the number of cruise passengers has reached more than $7 \%$ since 1990. Since 2002, the average number of cruise passengers has raised to one million persons every year (Domènech et al, 2019). This rise is reflected not only in passengers' numbers but also in the appearance of new destinations for a cruise ship (London et al., 2017). Today, cruise tourism is no longer a luxurious place for hospitality, but it is considered as mass tourism. Cruising has become more reachable for younger partners, families, holiday seekers, and low-income guests; this is because the cruise fares have decreased as a result of the sharp competition (Domènech et al., 2019). The cruise industry has transferred from being means of transportation into a complete travel destination that provides leisure and entertainment to tourists. Recent cruise ships can be regarded as floating resort hotels that offer services as sightseeing channels with fine dining restaurants, food courts, shopping centers, and entertainment outlets. Cruises have been recently increased in size to provide extra on-board services and amenities to guests, together with varieties in lodging facilities (Lyu et al., 2017).

Nile Cruises have their own distinction and attraction on the Nile in Egypt. Nile cruise trips have gained very good reputation among tourists and become one of the fascinating destinations. Some tourists regard Nile cruises not only as a place for entertainment but also as a real place for passing the historical and archaeological sites while tour guides explain in details the Pharaonic stories and heritage (Farag and ElAlfy, 2013).

The cruise ship has recently obtained an increasing and admirable worldwide demand and regarded as the rapidly growing trend in the tourism market. However, there are some social, economic, and environmental challenges confronting cruise ship due to the environmental deterioration, air pollution, unhealthy waste disposal practices, unmanageable infrastructure, and the continuous unplanned maintenance in ports. Moreover, in some destinations, some safety and security challenges that have a negative influence on cruise guests' loyalty. This is exemplified in the fragile ecosystem, the terrorists and pirates' attacks on a cruise ship or ports, natural disasters and unexpected bad climate. The cruise technical problems resulted also from the technical application mistakes representing real safety and security problems usually confronting cruise management. These technical problems require a regular program for maintenance together with an application system to improve marine life and save power on board (Wondirad, 2019).

\section{Literature review}

\section{Cruise industry growth}

The cruise field has witnessed a remarkable development during the last 30 years. It has become a new career in the shipping industry, especially after the increasing demand for cruising with new ships (Alkan et al, 2015). In the 1960s, the Caribbean region has 
upgraded itself as an admirable destination for the cruise ship. Accordingly, various destinations have become an active place for the cruise market. Two renowned cruise ship companies (Carnival Corporation and Royal Caribbean Cruises) started to control two - third of the world cruise market with their sister companies (Polat, 2015). Nowadays, cruise ships are regarded as one of the important tourism types, not just means of transportation. It is seen as a highly developed tourism product that includes entertainment and lodging plus offering an all-inclusive holiday (Salti, 2019).

The cruise sector is a rapidly growing international tourism trend (Sharples, 2019). Cruise tourism is regarded as a great component of mass tourism. Although it is one of the elite markets at the beginning of the $20^{\text {th }}$ century, it has become now one of the important types of mass tourism owing to the development of commercial aviation (Navarro-Ruiz et al, 2019).

It has been proved through the statistical data of Cruise Lines International Association (CLIA) that the international cruise tourism has been developed with an annual growth of $\% 4.2 \%$ over the last 10 years, and from 17.8 million passengers in 2009 to 24.7 million passengers in 2016 (Artal-Tur, et al, 2019). The number of passengers increased to reach 25.80 million passengers in 2017. A further increase is expected to reach 37.60 million persons in 2025, the fact that reflects cruise ship progression as a potential market (Wang, 2019). Consequently, cruise owners began to purchase big-size ships so as to be able to accommodate over 6,000 passengers and over 2,000 persons of ship staff (Penco et al, 2019).

\section{Table 1}

Number of cruise passengers worldwide (2009-2017).

\begin{tabular}{|c|c|}
\hline Year & Number (million) \\
\hline 2009 & 17.80 \\
\hline 2010 & 19.10 \\
\hline 2011 & 20.50 \\
\hline 2012 & 20.90 \\
\hline 2013 & 21.30 \\
\hline 2014 & 22.34 \\
\hline 2015 & 23.19 \\
\hline 2016 & 24.70 \\
\hline 2017 & 25.80 \\
\hline
\end{tabular}

Source: Gouveia, A. X., and Eusébio, C. (2019), PP. 422-438

\section{River Cruising: Key Features}

To compare between marine cruises and river cruises, river cruises have special limited qualities pertaining to the nature of sailing like the cruise tour, services and facilities offered on board and then, the whole tour program of the river cruise. No doubt that the size of ships for the river is smaller in size than the ships on the sea and oceans. Consequently, the services and facilities offered in river cruises are more limited than that of sea cruises. The limitation also involves the number of passed sites such as ports, cities, natural sites and tourist attractions (Ružić, 2018). 


\section{The Impacts of Cruise Industry}

\section{- Economic Impacts}

The cruise business plays an active role in the growth of many local economies (Vaya et $a l$, 2018). This constructive economic impact includes the creation of job opportunities for job seekers, the high volume of sales coming from passengers' money payments, cruise operation, expended money on ports, governmental profits and infrastructure and superstructure development of destinations (De Grosbois, 2016). The cruise industry provides direct, indirect, and induced economic benefits. The direct benefits are embodied in passengers' direct payment on food and beverage service, souvenirs, transportation, hotel accommodation, and tour guide services. The indirect benefits involve the profits gained by companies and suppliers of goods and services delivered to the cruises. Induced benefits include the income invested by local corporates and residents, which might support local development (Pino and Peluso, 2018). The CLIA reports in 2015 recorded that cruise benefits reached $\$ 117$ billion and the creation of 956,000 full-time job vacancies (Lopes, and Dredge, 2018). Moreover, the CLIA report in 2017 revealed that cruise tourism business created more than one million full-time job opportunities and shared with approximately 134 billion USD in the global economy (Wondirad, 2019).

\section{- Socio- cultural Impact}

The cruise business also has an important influence on local communities. The contact between the tourist destination inhabitants and cruise guests create mutual cultural learning and exchange. However, the cruise tourism field can have a negative effect in terms of causing noise pollution, crime and harassment, the harm of national traditions and customs, negative impact on local heritage and ethics (De Grosbois, 2016).

Cruise tourism can also cause "Population pollution" which means the over-capacity of visitors on ports and marine life. Although residents are benefited from the large number of visitors that represent a real investment, they neglect the environment preservation of the tourist destination and surely become irresponsible for any damage to the quality of life (McCarthy, 2018).

\section{- Environmental impact}

The environmental impact of cruise tourism is an important issue that opposes its growth. Despite of creating the innovative "clean technologies" and transportation of a large number of passengers, the cruise ship harms the ecosystem of marine life due to water emancipation and air pollution (Pino and Peluso, 2018). Cruise ships lead to the existence of polluted water brooks such as oily rubbish water, water weight, and air release resulted from the burnt fuel. This is plus the human waste and oven ashes (Baker et al, 2013).

It is important to consider the ecosystem issues as a highly important one to minimize the undesirable influence on the environment. According to the reports of the Earth International in 2014, many cruises have been categorized as environmentally friendly associations. A lot of efforts have been exerted to protect the environment. First, they applied the recycling system for 2 years. As a result, the waste decrease reached $5 \%$ per year to be reprocessed and recovered to energy. Accordingly, the petroleum energy was also reduced. Second, the power-saving LED lights were fixed to maximize power 
effectiveness and minimize petroleum usage and oil spills (Han et al, 2019). Because of the fast- growing cruise tourism, sustainability has become one of the most significant issues in this business. This leads to the application of sustainable rules in cruises' operation, management, and branding programs (Ponton, and Asero, 2018).

\section{Challenges affecting the cruise Industry}

This fast development of cruise tourism is also confronted with some difficult challenges such as:

\section{- Security and safety}

Safety and security is the trademark of cruising. However, there have always been hazards related to transportation via sea or ocean, natural catastrophe, and human-made risks. The development of the world law of terrorists has forcefully resulted in protective interest in safety and security practices. Safety and security aspects of the cruise are protecting cruises from accidents (e.g. ship flooding or fire) and direct terrorization (e.g. hijacking or terrorism) (Najafipour et al, 2014). The International Maritime Organization (IMO) identifies "maritime security" and "maritime safety" as means of defending and safeguarding cruise ships, passengers, cruise staff, shipment, and maritime ecosystems (Nguyen and Annaraud, 2018).

\section{- Qualified human power}

The cruise operation needs a sufficient number of qualified staff. The cruise management corporation is mostly entailing two divisions: ship operation and the hospitality section. The cruise captain is managing the cruise with the assistance of security, operational and sea crew (Dowling and Weeden, 2017). The cruise field requires high caliber and skillful manpower that effectively influences guests' experience. Cruise staff need to work continuously with different nationalities of guests, the fact that requires very good communication and language skills. Moreover, cruise staff needs to work for a longer time and have the ability to leave their families and friends for a long duration during cruise work (Nguyen and Annaraud, 2018).

\section{- Service quality and innovation}

The cruise quality of service is measured by delivering excellent services to exceed customers' expectations. Food and beverage products and services, accommodation's amenities, leisure, and tour organization are also a highly important factor for affecting customers' satisfaction. This is plus the charming climate and views in cruise destinations. Moreover, it is significant to mention that courteous services of the staff and gentle communication add value to cruise experience (Dipietro and Peterson, 2017). Many cruise companies categorize cruise quality as the most crucial element for customer satisfaction in terms of creating a friendly relationship between the cruise and accommodated guests. If there is no guests' satisfaction, cruise sales will decrease and operation will prove failure (Han et al., 2019). The cruise quality of service entails 3 dimensions: (1) quality of the physical environment that includes cruise atmosphere, architecture and social matters. (2) Attitude and behavior of cruise employees with gentle relationship (3) Cruise hospitality services such as accommodation, food and beverage services, leisure and amenities (Chua, et al, 2019). The cruise tourism industry is planning for innovative platforms for cruise growth, improvement and extended tourism activities. Innovation does not only mean the new cruise design, but also 
innovative products and services, new tourists' programs, and new marine systems (Guerra et al, 2019).

\section{- The Legal Environment}

The national legislation might maximize the imposed taxes and add some constraints on tourists' travel as part of the political, social and environmental programs. This legislation may increase the number of inbound tourists to ports. However, on the other side, firm legislation may create some routine limitations to cruise business in many countries (Delgado, 2017).

\section{- Smart Cruise Ships}

Technology is transferring the cruises into smart floating hotels. Recent technology has created a radical change to the cruise industry that necessitates cruises to interact with the current technology elements such as IMAX cinema, The Thrill 5 D Theatres, mobile applications, GPS mapping and 3D printers. If the cruise ship in any country does not come up with recent technology, it can't compete in the tourism market (Vafeidou, 2019).

\section{- Health Issues}

Health issues, associated with cruises' guests and staff, are one of the recent top priority critical subjects in the current cruise ship industry's researches and studies, due to the health accidents that recently emerged on board (Liu-Lastres et al, 2019). Varieties and complication of developed health diseases on- board have increased during the last 30 years. In the 1980s and 1990s epidemics have mostly resulted from food bacteria contamination like Shigella, Salmonella, and Escherichia Coli (Dowling and Weeden, 2017). If the outburst diseases are not successfully controlled, the health problems will be transferred into a disaster that surely will lead to guests' dissatisfaction, revenue decrease, possible legal penalty, and a bad reputation. The start of a crisis on a cruise ship might also influence negatively passengers' potential demand and maximize risk observation from tourists' side, the fact that certainly decreases sales and profitability of the cruise (Liu-Lastres et al., 2019). If there are a protective food safety program and healthy beverage standards, food contamination ratios will be decreased and food safety problems will be diminished (Dowling and Weeden, 2017).

\section{- COVID-19 and Cruise Industry}

Coronavirus infectious illness (COVID-19) epidemic firstly appeared in Wuhan City, China on $31^{\text {st }}$ Dec. - 2019. World Health Organization (WHO) was advised with the existence of an unfamiliar infectious virus on that day. Chinese governmental associations have acknowledged this new virus. Many COVID-19 cases have been emerged in various cruise ships (Ege, 2020). Cruise ships at once recognized increased cases and witnessed some bad COVID-19 situations in the international tourism system. In February- 2020, at least 25 cruise ships of Diamond Princess had recorded some COVID 19 infection cases. By the end of March 2020, around 10 cruise ships set at sea with no permission to port. Generally, cruise ships are known for the virus infections due to the unopened atmosphere, the direct contact of different nationalities, and crew transmission between ships (Gössling et al, 2020). 
COVID-19 infections have recorded very serious cases worldwide. The epidemic appeared in many cruise ships in many tourist destinations and has become too difficult to control it. This is due to a large number of guests' cabins within the narrow space of the cruise, as well as the constant interaction and dealings of tourists (Liu and Chang, 2020).

Table 2

Coronavirus on cruise ships

\begin{tabular}{|c|c|c|c|}
\hline Ship & Location & $\begin{array}{l}\text { Covid-19 } \\
\text { reported }\end{array}$ & Scale of outbreak \\
\hline $\begin{array}{l}\text { Diamond } \\
\text { Princess }\end{array}$ & Japan & $\begin{array}{l}4 \text { February } \\
2020\end{array}$ & $\begin{array}{l}\text { 700+ passengers and crew infected, nine } \\
\text { died }\end{array}$ \\
\hline $\begin{array}{c}\text { Grand } \\
\text { Princess }\end{array}$ & San Franciso & $\begin{array}{l}9 \text { March } \\
2020\end{array}$ & $\begin{array}{l}\text { Two passengers, one crew member died. } \\
100+\text { tested positive during Hawaii } \\
\text { cruise }\end{array}$ \\
\hline $\begin{array}{c}\text { Ruby } \\
\text { Princess }\end{array}$ & Australia & $\begin{array}{l}19 \text { March } \\
2020\end{array}$ & $\begin{array}{l}11 \text { passengers died, at least } 662 \\
\text { passengers and crew were infected. Ship } \\
\text { blamed for } 10 \% \text { of Australia's cases }\end{array}$ \\
\hline $\begin{array}{c}\text { Greg } \\
\text { Mortimer }\end{array}$ & Uruguay & $\begin{array}{l}27 \text { March } \\
2020\end{array}$ & $\begin{array}{l}\text { One crew member died, at least } 128 \\
\text { passengers and crew infected }\end{array}$ \\
\hline $\begin{array}{c}\text { Coral } \\
\text { Princess }\end{array}$ & $\begin{array}{c}\text { South } \\
\text { America/Florida }\end{array}$ & $\begin{array}{l}\text { 1 April } \\
2020\end{array}$ & $\begin{array}{l}\text { Three passengers died. Ship not allowed } \\
\text { to dock in South America }\end{array}$ \\
\hline $\begin{array}{c}\text { Costa } \\
\text { Atlantica } \\
\end{array}$ & Japan & $\begin{array}{l}23 \text { April } \\
2020\end{array}$ & $\begin{array}{l}148 \text { crew members tested positive, as the } \\
\text { ship remained at the dock for repairs }\end{array}$ \\
\hline
\end{tabular}

Source: Guardian, 2020.

\section{- Infrastructure challenges}

Many tourist destinations do not have complete infrastructure including the construction of shipping paths and tracks. It is highly important to develop the tourist destination infrastructure to cope with climate change and eco- impact (Lester et al, 2016). Harbor infrastructure is regarded as one of the top priority issues especially after the rapid growth of cruise tourism. Consequently, ports' development recently become a new trend including water depth, expansion of offshore space, lengthening of shoreline, construction of security fence and development of engineering technology (Sun et al, 2014)

\section{- Marketing}

Cruise marketing has recently witnessed a quick shift as the customers' wants and desires become more innovative. As for advertising, cruise companies are decreasing their TV commercial time but increasing online advertising through different social media, such as YouTube, Facebook, Twitter, and Instagram. (Nguyen and Annaraud, 2018) 


\section{Research methodology}

\section{The Pilot Study}

A pilot study has been implemented with 3 floating hotels' managers and one representative of the Egyptian Hotel Association specialized in Nile Cruises' activities and administration. The pilot study has been done in Oct. 2019. The results of the study are summarized in the following:-

- According to the Ministry of Tourism Report, Oct-2019, the total number of operating Nile Cruises' ships (Floating Hotels) reached 140 out of 297 licensed floating hotels i.e. the operating floating hotels represent $46.66 \%$ of the licensed ones.

- Cruise ships had exposed to severe crises from 2011-2014 to the extent that 90\% of the floating hotels had completely stopped their work activities and operation during that time.

- 30\% of floating hotels started cruise operation from 2014 to date of present study.

- The main problems facing Egyptian Nile Cruises are related to licensing, floating hotels' maintenance problems, unqualified staff, and difficulty in cruise ships' renovation.

\section{Research Objectives}

The main goal of the study is to support the revitalization of the Egyptian Nile Cruises' activities, services and management, after a long period of work stagnation, resulted from series of crises, through the following objectives:

- Providing a comprehensive recent profile about the current situation of Egyptian Nile Cruises after sequences of confronted crises.

- Identifying opportunities for Egyptian Nile Cruises' revitalization as well as returning back to the normal tourist activities.

- Identifying the main challenges threatening Egyptian Nile courses' revitalization.

- Providing proposals for the revitalization and development of the Egyptian Nile Cruises.

\section{Research Questions}

1. To what extent the Nile Cruises' management has been negatively affected by the unstable events and critical circumstances passed in Egypt since 2011?

2. What are the main negative impacts on Nile Cruises' management, resulting from the unstable events and critical circumstances passed in Egypt since 2011?

3. Are there any prospects for Nile Cruise management's revitalization?

4. What are the current indicative elements of Nile Cruises' revitalization and constructive development?

5. What are the opportunities for and challenges against Nile Cruises' revitalization?

6. Are there any forecasts and predictions for the quick recovery of Nile Cruises' activities and services after the end of the COVID-19 crisis? 
The first five questions were proposed for the study analysis from the beginning of the research. However, question number 6 has been unexpectedly added due to the emerged outbreak of COVID-19 infection in some of the floating hotels as well as due to the Egyptian authorities' decisions for blocking the Nile Cruises' operational activities.

\section{Research Duration and Sampling}

The duration of the field survey lasted for 6 months starting from $1^{\text {st }}$ Nov- 2019 till $30^{\text {th }}$ Apr- 2020. According to the Egyptian Hotel Guide, 2015-2016, the total number of operating Nile cruises' ships (Floating Hotels) was 140 floating hotels which represent $46.66 \%$ of the total number of licensed floating hotels. However, the total number of operating Nile Cruises during the date of the survey in March and April, 2020, did not exceed 40 floating hotels due to the COVID 19 crisis. Hence, the research sample hardly reached 35 floating hotels.

\section{Field Survey Analysis Tools}

A quantitative approach is adopted in this study by using a questionnaire survey to gather primary data. The main purpose of the questionnaire is to provide a general upto-date picture of the current situation of Egyptian Nile Cruises' operation and management. The questionnaire has been distributed among the general managers of the sampled floating hotels. It was planned to distribute the questionnaire among employees working in the operational departments. However, due to the downsizing of the work capacity during COVID 19 crisis, there were very few numbers of present employees and it was too hard to reach them as most of workers were in unpaid leave. Thus, questionnaires have been distributed among the general managers. The questionnaire format includes six main sections. The first section addresses the basic data of selected floating hotels through multiple choice questions about star classification, management type, and capacity. The second section aims at exploring the reasons behind stopping the Nile Cruises' operation and tourism activities. Section three discusses the negative impacts that resulted from the floating hotels' stagnation period. The fourth section is talking about the reasons for returning back of some floating hotels to operation and cruise activities after years of inactivity. The main purpose of the fifth section is to know renovations' elements for Egyptian Nile Cruise ships after a long time of stagnation. Finally, the sixth section includes four questions concerned with COVID 19 Crisis.

A qualitative approach has been utilized to analyze the interview questions. The interview has been also conducted with the general managers of the sampled Nile Cruises (Floating Hotels). It contains 3 main parts: The first part of the interview is discussing the opportunities that support and develop revitalization of Egyptian Nile Cruises. The second part of the interview is concerned with the challenges confronting Nile Cruises' management in Egypt that hinder its renovation and development. Finally, the third part involves the recommendation for the revitalization of Egyptian Nile Cruises.

\section{Statistical Methods}

In this study, Cronbach's alpha is used to assess the reliability of the data. This is because Cronbach's alpha is a meaningful measure of the internal consistency of a survey. The results showed that the alpha coefficient was 0.799 . Therefore, these results 
were considered reliable. Data analysis was conducted using the Statistical Package for Social Sciences (SPSS) version 20. Appropriate Descriptive statistics, including: frequencies; percentage; mean; standard deviation; rank, were produced to provide a general summary of the data , T-Test to identify the differences between the respondents according to floating hotel management type and analysis of variance (ANOVA) to identify the differences between the respondents according to star classification.

\section{Results and discussion}

\section{First: Questionnaire Analysis}

- The general profile of the research sample

This section shows the main characteristics of the investigated floating hotels, including: - star classification, management type, and capacity.

Table 3

Profile of the investigated floating hotels

\begin{tabular}{|l|l|l|}
\hline \multicolumn{1}{|c|}{ Star Classification } & Frequency & \multicolumn{1}{c|}{ Percent $\%$} \\
\hline 5 stars & 23 & 65.7 \\
\hline 4 stars & 7 & 20 \\
\hline 3 stars & 5 & 14.3 \\
\hline Total & 35 & 100 \\
\hline Floating Hotel Management type & Frequency & Percent\% \\
\hline Chain & 21 & 60 \\
\hline Independent & 14 & 40 \\
\hline Total & 35 & 100 \\
\hline Floating Hotel capacity & Frequency & Percent\% \\
\hline less than 50 cabins & 9 & 25.7 \\
\hline $50-100$ cabins & 19 & 54.3 \\
\hline $101-200$ cabins & 7 & 20 \\
\hline More than 200 cabins & - & - \\
\hline Total & 35 & 100 \\
\hline
\end{tabular}

Table 3 indicated that $65.7 \%$ of the sample is five-star floating hotels, $20 \%$ of the sample is four-star floating hotels and $14.3 \%$ of the samples are three-star floating hotels. $60 \%$ of the samples are chain hotels and $40 \%$ of the sample is independent hotels. $54.3 \%$ of the investigated floating hotels have $50-100$ cabins, followed by floating hotels that have less than 50 cabins. Moreover, 20\% of the sample has from 101 -200 cabins.

\section{Table 4}

Recent shuts of floating hotels.

\begin{tabular}{|c|l|l|l|l|}
\hline Factor & Year & Frequency & Percent \% & Rank \\
\hline \multirow{2}{*}{$\begin{array}{l}\text { When the floating hotel stopped } \\
\text { operation and froze all tourist } \\
\text { activities }\end{array}$} & 2011 & 16 & 46 & 1 \\
\cline { 2 - 5 } & 2012 & 9 & 26 & 2 \\
\cline { 2 - 5 } & 2013 & 5 & 14 & 3 \\
\cline { 2 - 5 } & Others & 5 & 14 & 3 \\
\hline Total & 35 & $100 \%$ & \\
\hline
\end{tabular}


From Table 4 , it can be seen that $46 \%$ of the sample stopped operation and froze all tourist activities in 2011, followed by $26 \%$ in 2012 , and $14 \%$ in $2013.14 \%$ goes for others, since some of them stopped in 2011 for one year only and returned back in 2013 for one year. Then, stopped again in 2014 and returned in 2017 till March 2020. Other floating hotels stopped for 3 months in 2011 and returned, then stopped again for another 4 months only just after the 30th June revolution and returned back again. All floating hotels have stopped in first April- 2020 due to the COVID 19 crisis.

Table 5

Years of stagnation.

\begin{tabular}{|l|l|l|l|l|}
\hline Factor & Variables & Frequency & Percent \% & Rank \\
\hline \multirow{3}{*}{$\begin{array}{l}\text { How many years your } \\
\text { floating hotels stopped wo operational activities? }\end{array}$} & Five years & 14 & 40 & 1 \\
\cline { 2 - 5 } & Four years & 5 & 14.2 & 3 \\
\cline { 2 - 5 } & Three years & 9 & 25.7 & 2 \\
\cline { 2 - 5 } & Two years & 3 & 8.7 & 4 \\
\hline & One year & 2 & 5.7 & 5 \\
\cline { 2 - 5 } & $\begin{array}{l}\text { Less than one } \\
\text { year }\end{array}$ & 2 & 5.7 & 5 \\
\hline \multicolumn{2}{|l|}{} & 35 & $100 \%$ & \\
\hline
\end{tabular}

Table 5 clarifies that $40 \%$ of the sample stopped five years with no operational activities, followed by $25.7 \%$ of the sample stopped their operational activities for three years, while $5.7 \%$ of the sample stopped for one year and less.

\section{Table 6}

The year of returning to service and operation

\begin{tabular}{|l|l|l|l|l|}
\hline & Year & Frequency & Percent\% & Rank \\
\hline \multirow{3}{*}{$\begin{array}{l}\text { Which year your floating } \\
\text { has returned? }\end{array}$} & 2014 & 7 & 20 & 2 \\
\cline { 2 - 6 } & 2015 & 5 & 14.3 & 3 \\
\cline { 2 - 6 } & 2016 & 5 & 14.3 & 3 \\
\cline { 2 - 6 } & 2017 & 12 & 34.4 & 1 \\
\cline { 2 - 6 } & 2018 & 3 & 8.5 & 4 \\
\cline { 2 - 6 } & 2019 & 3 & 8.5 & 4 \\
\hline \multicolumn{2}{|l|}{ Total } & 35 & $100 \%$ & \\
\hline
\end{tabular}

From table 6 demonstrates that $34.4 \%$ of the sample has returned since $2017,20 \%$ of the sample has returned since 2014 and $8.5 \%$ of the sample returned in 2019 .

Table 7

Number of years of floating hotels' operation after a long period of stopping

\begin{tabular}{|c|c|c|c|c|}
\hline & Years & Frequency & Percent $\%$ & Rank \\
\hline \multirow{5}{*}{$\begin{array}{l}\text { How many years of operation } \\
\text { your floating hotel passed } \\
\text { after a long period of } \\
\text { stopping? }\end{array}$} & Five years & 7 & 20 & 2 \\
\hline & Four years & 7 & 20 & 2 \\
\hline & Three years & 15 & 42.8 & 1 \\
\hline & Two years & 3 & 8.5 & 3 \\
\hline & One year & 3 & 8.5 & 3 \\
\hline \multicolumn{2}{|l|}{ Total } & 35 & $100 \%$ & - \\
\hline
\end{tabular}


Table 7 shows that $42.8 \%$ of investigated floating hotels have operated for three years after a long period of stagnation and $20 \%$ of the investigated floating hotels have operated for four years and another 20\% of them operated for five years. Moreover, only $8.5 \%$ worked for two years and another $8.5 \%$ worked for one year after a long time of stagnation.

\section{Table 8}

Reasons of the floating hotels' closure

\begin{tabular}{|r|l|c|c|c|}
\hline No & \multicolumn{1}{|c|}{ Reasons } & Mean ${ }^{*}$ & SD & Rank \\
\hline 1 & Low demand due to the revolutions' crisis & 4.77 & 0.942 & 1 \\
\hline 2 & No manpower for operation and working & 2.68 & 0.676 & 2 \\
\hline 3 & $\begin{array}{l}\text { Increase in licensing costs that limits the } \\
\text { budget and leads to financial inadequacy }\end{array}$ & 1.82 & 0.984 & 3 \\
\hline 4 & Increase in Marine rental rates & 1.82 & 0.984 & 3 \\
\hline
\end{tabular}

*Mean of agreeing with the reasons, where: $1=$ strongly disagree; $2=$ disagree; $3=$ neutral; $4=$ agree; $5=$ strongly agree. $\mathrm{SD}=$ standard deviation

As detailed in the previous table, the first reason behind stopping the floating hotels' operation and tourism activities is low demand due to the revolutions' crisis with mean of (4.77) and std. deviation of (0.942). The second reason is no manpower for operation and working with mean of (2.68) and std. deviation of (0.676), followed by an increase in licensing costs that limits the budget and leads to financial inadequacy and an increase in marine rental rates with mean of (1.82) and std. deviation of (0.984) . Another reason by respondents is no safety and security due to the events of the revolution. Nowadays all the Nile Cruises stopped due to the COVID 19 crisis.

\section{Table 9}

Independent samples T-test between the investigated floating hotels according to management type regarding the main reasons behind stopping the floating hotels' operation and tourism activities.

\begin{tabular}{|l|c|c|c|c|}
\hline Reasons & Management type & Mean & $\mathrm{T}$ & \multirow{2}{*}{ Sig. (2-tailed) } \\
\hline $\begin{array}{l}\text { Low demand due to the } \\
\text { revolutions' crisis }\end{array}$ & Chain & 4.81 & 0.377 & 0.708 \\
\cline { 2 - 3 } $\begin{array}{l}\text { No manpower for operation and } \\
\text { working }\end{array}$ & Independent & 4.69 & & \\
\hline & Chain & 2.63 & -0.556 & 0.582 \\
\hline $\begin{array}{l}\text { Increase in licensing costs } \\
\text { that limits the budget and } \\
\text { leads to financial inadequacy }\end{array}$ & Independent & 2.76 & & \\
\cline { 1 - 3 } Increase in Marine rental rates & Independent & 1.72 & -0.787 & 0.437 \\
\cline { 2 - 3 } & Chain & 1.72 & -0.787 & 0.437 \\
\hline
\end{tabular}

As shown in Table 9, there are insignificant differences between the chain and independent floating hotels concerning the reasons behind stopping their operation and tourism activities. 


\section{Table 10}

Variance analysis between the investigated floating hotels according to star classification regarding the main reasons behind stopping the floating hotels' operation and tourism activities using ANOVA test

\begin{tabular}{|c|c|c|c|c|}
\hline Reasons & $\begin{array}{c}\text { Star } \\
\text { classification }\end{array}$ & Mean & $\mathrm{F}$ & Sig. \\
\hline \multirow{3}{*}{$\begin{array}{l}\text { Low demand due to the } \\
\text { revolutions' crisis }\end{array}$} & 5 stars & 4.60 & \multirow[t]{3}{*}{0.762} & \multirow[t]{3}{*}{0.475} \\
\hline & 4 stars & 5.00 & & \\
\hline & 3 stars & 5.00 & & \\
\hline \multirow{3}{*}{$\begin{array}{l}\text { No manpower for operation } \\
\text { and working }\end{array}$} & 5 stars & 2.60 & \multirow[t]{3}{*}{0.407} & \multirow[t]{3}{*}{0.669} \\
\hline & 4 stars & 2.75 & & \\
\hline & 3 stars & 2.85 & & \\
\hline \multirow{3}{*}{$\begin{array}{l}\text { Increase in licensing costs } \\
\text { that limits the budget and } \\
\text { leads to financial inadequacy }\end{array}$} & 5 stars & 2.10 & \multirow[t]{3}{*}{1.874} & \multirow[t]{3}{*}{0.170} \\
\hline & 4 stars & 1.50 & & \\
\hline & 3 stars & 1.42 & & \\
\hline \multirow{3}{*}{$\begin{array}{l}\text { Increase in Marine rental } \\
\text { rates }\end{array}$} & 5 stars & 2.10 & \multirow[t]{3}{*}{1.874} & \multirow[t]{3}{*}{0.170} \\
\hline & 4 stars & 1.50 & & \\
\hline & 3 stars & 1.42 & & \\
\hline
\end{tabular}

As detailed in Table 10, the results of the ANOVA test revealed that the significance levels were more than 0.05 which means that there were no statistically significant differences between star classification with relation to reasons behind stopping the floating hotels' operation and tourism activities.

\section{Table 11}

The rate (percentage) of the financial loss against the targeted profit, your floating hotel planned during the last five years.

\begin{tabular}{|c|c|c|c|c|}
\hline Factor & $\begin{array}{l}\text { Percentage of } \\
\text { the financial loss }\end{array}$ & Frequency & Percent $\%$ & Rank \\
\hline \multirow{5}{*}{$\begin{array}{l}\text { What is the rate (percentage) of } \\
\text { the financial loss against the } \\
\text { targeted profit, your floating } \\
\text { hotel planned during the last } \\
\text { five years? }\end{array}$} & $\% 100$ & - & - & - \\
\hline & $\% 75-99$ & - & - & - \\
\hline & $\% 50-74$ & 14 & 40 & 1 \\
\hline & $\% 25-49$ & 12 & 34.3 & 2 \\
\hline & Less than \% 25 & 9 & 25.7 & 3 \\
\hline \multicolumn{2}{|l|}{ Total } & 35 & $100 \%$ & \\
\hline
\end{tabular}

According to the above table, it is obvious that $40 \%$ of the sample mentioned the rate (percentage) of the financial loss against the targeted profit was between $-50-74 \%$. $34.3 \%$ of the sample, their financial loss against the targeted profit was between 49 $25 \%$ 


\section{Table 12}

The rate (percentage) of manpower that has been fired and/or left the job during the stagnation period of your floating hotel

\begin{tabular}{|l|l|l|l|l|}
\hline Factor & $\begin{array}{l}\text { Manpower that } \\
\text { has been fired }\end{array}$ & Frequency & Percent\% & Rank \\
\hline What is the rate (percentage) of & $\% 100$ & - & - & - \\
\cline { 2 - 5 } \multirow{2}{*}{$\begin{array}{l}\text { manpower that has been fire } \\
\text { and/or left the job during the } \\
\text { stagnation period of your floating } \\
\text { hotel? }\end{array}$} & $\% 99-75$ & 5 & 14.3 & 3 \\
\cline { 2 - 6 } & $\% 74-50$ & 9 & 25.7 & 2 \\
\cline { 2 - 5 } & Less than\% 25 & 12 & 34.3 & 1 \\
\hline Total & 35 & $100 \%$ & \\
\hline
\end{tabular}

Results in table 12 illustrated that $40 \%$ of the sample mentioned the rate (percentage) of manpower that have been fired and/or left the job during the stagnation period was Less than\% 25.

Table 13

Negative effects resulted from the floating hotels stagnation period

\begin{tabular}{|r|l|c|c|c|}
\hline No & \multicolumn{1}{|c|}{ Items } & Mean $^{*}$ & SD & Rank \\
\hline 1 & Financial loss and profitability decrease & 4.57 & 0.884 & 1 \\
\hline 2 & $\begin{array}{l}\text { Leakage of qualified and trained } \\
\text { workers }\end{array}$ & 3.54 & 1.196 & 3 \\
\hline 3 & $\begin{array}{l}\text { Loss of distinctive and lucrative } \\
\text { customers }\end{array}$ & 4.42 & 0.850 & 2 \\
\hline 4 & Engineering and maintenance costs & 4.42 & 4 \\
\hline
\end{tabular}

*Mean of agreeing with the negative effects, where: $1=$ strongly disagree; $2=$ disagree; $3=$ neutral; $4=$ agree; $5=$ strongly agree. $\mathrm{SD}=$ standard deviation

Table 13 reveals that there are four negative effects resulted from the Nile Cruises' stagnation period which is ranked as follows: The first item is financial loss and profitability decrease with mean of (4.57) and std. deviation of (0.8840). The second item is engineering and maintenance costs with a mean of (4.42) and std. deviation of (0.8501). The third item is the leakage of qualified and trained workers with a mean of (3.54) and std. deviation of (1.1966). The fourth item is the loss of distinctive and lucrative customers the respondents mentioned that there are other negative effects such as: Floating hotels costs such as marine rentals and permissions of sailing plus licenses during stagnation period with no profits or returns, moreover floating hotels' costs are 25\% higher than the traditional hotels. This is plus the furniture and equipment in the cabins are shorter in life than the furniture and equipment in the guest rooms within traditional hotels, and the costs are very high as it costs 105 thousand pounds per week to cover the fuel costs plus the engineering costs. Moreover, this finding concurs with the study of Sun et al, (2014). They stated that the infrastructure is regarded as one of the top priority issues especially after the rapid growth of cruise tourism. Furthermore, the revenue of the floating hotels have been decreased after 2011. Before 2011 it reached Euro 100 but after 2011 it reached Euro 25 due to the charter flights. Finally, 
losing the positive image and guests' word of mouth is regarded as one of the main negative impacts.

\section{Table 14}

Independent samples T-test between the investigated floating hotels according to management type regarding negative effects resulted from the stagnation period

\begin{tabular}{|l|c|c|c|c|}
\hline Reasons & $\begin{array}{c}\text { Management } \\
\text { type }\end{array}$ & Mean & T & Sig. (2-tailed) \\
\hline $\begin{array}{l}\text { Financial loss and } \\
\text { profitability decrease }\end{array}$ & Chain & 4.4091 & -1.435 & 0.16 \\
\cline { 2 - 5 } & Independent & 4.8462 & & 0.78 \\
\hline $\begin{array}{l}\text { Leakage of qualified and } \\
\text { trained workers }\end{array}$ & Chain & 3.5000 & -0.272 & \\
\hline $\begin{array}{l}\text { Loss of distinctive and } \\
\text { lucrative customers and }\end{array}$ & Independent & 3.6154 & & 0.53 \\
\hline $\begin{array}{l}\text { Engineering } \\
\text { maintenance costs }\end{array}$ & Independent & 3.6154 & 1.747 & .098 \\
\cline { 2 - 3 } & Chain & 4.6364 & & \\
\cline { 2 - 3 } & Independent & 4.0769 & & \\
\hline
\end{tabular}

Table 14 shows that an independent-samples $t$-test was conducted to examine the difference between chain and independent floating hotels. The results of the independent-samples $t$-test showed that a total of 4 negative effects have recorded insignificant differences between chain and independent.

\section{Table 15}

Variance analysis between the investigated floating hotels according to star classification regarding negative effects resulted from the stagnation period using ANOVA test

\begin{tabular}{|c|c|c|c|c|}
\hline Reasons & $\begin{array}{c}\text { Star } \\
\text { classification }\end{array}$ & Mean & $\mathrm{F}$ & Sig. \\
\hline \multirow{3}{*}{$\begin{array}{lll}\text { Financial loss } & \text { and } \\
\text { profitability decrease } & \end{array}$} & 5 stars & 4.5000 & \multirow[t]{3}{*}{0.218} & \multirow[t]{3}{*}{0.805} \\
\hline & 4 stars & 4.7500 & & \\
\hline & 3 stars & 4.5714 & & \\
\hline \multirow{3}{*}{$\begin{array}{l}\text { Leakage of qualified and } \\
\text { trained workers }\end{array}$} & 5 stars & 3.9000 & \multirow[t]{3}{*}{2.478} & \multirow[t]{3}{*}{0.100} \\
\hline & 4 stars & 3.2500 & & \\
\hline & 3 stars & 2.8571 & & \\
\hline \multirow{3}{*}{$\begin{array}{l}\text { Loss of distinctive and } \\
\text { lucrative customers }\end{array}$} & 5 stars & 3.7000 & \multirow[t]{3}{*}{1.097} & \multirow[t]{3}{*}{0.346} \\
\hline & 4 stars & 3.2500 & & \\
\hline & 3 stars & 2.8571 & & \\
\hline \multirow{3}{*}{$\begin{array}{l}\text { Engineering and maintenance } \\
\text { costs }\end{array}$} & 5 stars & 4.3000 & \multirow[t]{3}{*}{0.791} & \multirow[t]{3}{*}{0.462} \\
\hline & 4 stars & 4.7500 & & \\
\hline & 3 stars & 4.4286 & & \\
\hline
\end{tabular}

As shown in Table 15, the one-way ANOVA to analyze the differences between star classifications with relation to negative effects resulted from the floating hotel 
stagnation period. The results of the ANOVA test revealed that the significance levels were more than 0.05 which means that there were no statistically significant differences between 5 stars, 4 stars and 3 stars floating hotels with relation to these negative effects.

\section{Table 16}

The reasons for returning back to operation and tourism activities after years of stagnation and freezing

\begin{tabular}{|l|l|l|l|l|}
\hline No & Reasons & Mean $^{*}$ & SD & Rank \\
\hline 1 & Demand Increase in Luxor and Aswan visits & 4.48 & 0.612 & 2 \\
\hline 2 & Security stability & 5.00 & 0.000 & 1 \\
\hline 3 & $\begin{array}{l}\text { Implementation of development programs by } \\
\text { the Egyptian government }\end{array}$ & 2.02 & 1.070 & 3 \\
\hline 4 & Floating hotel change management & 2.02 & 1.070 & 3 \\
\hline
\end{tabular}

*Mean of agreeing with the reasons, where: $1=$ strongly disagree; $2=$ disagree; $3=$ neutral; $4=$ agree; $5=$ strongly agree. $\mathrm{SD}=$ standard deviation

The results, as shown in table 16, revealed that the reasons for returning to operation and tourism activities for floating hotels are "Security stability" at the first rank with mean of (5.00). This result is consistent with findings from the study of Najafipour et al, (2014) which showed that safety and security are the trademark of cruising. Demand increase in Luxor and Aswan visits came at the second rank and scored a mean of 4.48. At the third rank came " implementation of development programs by the Egyptian government and floating hotel change management and recorded the same mean score (2.02). Respondents mentioned other reasons as follows: Implementing marketing campaigns through signing a contract with some international advertising companies to promote for floating hotels abroad and shooting a promotional video film published in some French and German Satellite channels. This is plus signing a protocol with international travel agents in 2016 to guarantee the cruise reservation during the winter season from $1^{\text {st }}$ Nov. till $30^{\text {th }}$ Apr., and in summer season from $1^{\text {st }}$ May till $30^{\text {th }}$ Oct. This protocol lasted for 4 years till stopping the operation in the middle of March 2020 due to the infection of Corona Virus.

\section{Table 17}

Independent samples T-test between the investigated floating hotels according to management type regarding the reasons for returning to operation and tourism activities for floating hotels

\begin{tabular}{|c|c|c|c|c|}
\hline Reasons & Management type & Mean & $\mathrm{T}$ & Sig. (2-tailed) \\
\hline \multirow{2}{*}{$\begin{array}{l}\text { Demand Increase in Luxor } \\
\text { and Aswan visits }\end{array}$} & Chain & 4.50 & 0.177 & 0.861 \\
\hline & Independent & 4.46 & & \\
\hline \multirow{2}{*}{ Security stability } & Chain & 5.00 & - & - \\
\hline & Independent & 5.00 & & \\
\hline \multirow{2}{*}{$\begin{array}{l}\text { Implementation of } \\
\text { development programs by } \\
\text { the Egyptian government }\end{array}$} & Chain & 1.72 & \multirow[t]{2}{*}{-2.298} & \multirow[t]{2}{*}{ *.028 } \\
\hline & Independent & 2.53 & & \\
\hline \multirow{2}{*}{$\begin{array}{l}\text { Floating hotel change } \\
\text { management }\end{array}$} & Chain & 1.72 & \multirow[t]{2}{*}{-2.298} & \multirow[t]{2}{*}{ *.028 } \\
\hline & Independent & 2.53 & & \\
\hline
\end{tabular}

* Statistically-significant difference where $P$-value $<0.05$. 
The results of the independent samples $t$-test table 17 showed that differences were found to be statistically significant between the chain and independent floating hotels. In other words two of these reasons were significantly higher among independent floating hotels than chain floating hotels, i.e.: "Implementation of development programs by the Egyptian government" $(\mathrm{M}=2.53) \mathrm{t}=(-2.298)-\mathrm{P}<0.05$; "Floating hotel change management" $(\mathrm{M}=2.53, \mathrm{t}=(-2.298), \mathrm{P}<0.05$.

\section{Table 18}

Variance analysis between the investigated floating hotels according to star classification regarding the reasons for returning to operation and tourism activities for floating hotels using ANOVA test

\begin{tabular}{|c|c|c|c|c|}
\hline Reasons & $\begin{array}{c}\text { Star } \\
\text { classification }\end{array}$ & Mean & $\mathrm{F}$ & Sig. \\
\hline \multirow{3}{*}{$\begin{array}{l}\text { Demand Increase in Luxor } \\
\text { and Aswan visits }\end{array}$} & 5 stars & 4.5000 & \multirow[t]{3}{*}{0.036} & \multirow[t]{3}{*}{0.965} \\
\hline & 4 stars & 4.5000 & & \\
\hline & 3 stars & 4.4286 & & \\
\hline \multirow[t]{3}{*}{ Security stability } & 5 stars & 5.0000 & \multirow[t]{3}{*}{-} & \multirow[t]{3}{*}{ - } \\
\hline & 4 stars & 5.0000 & & \\
\hline & 3 stars & 5.0000 & & \\
\hline \multirow{3}{*}{$\begin{array}{ll}\text { Implementation } & \text { of } \\
\text { development programs by } \\
\text { the Egyptian government }\end{array}$} & 5 stars & 2.3000 & \multirow[t]{3}{*}{1.786} & \multirow[t]{3}{*}{0.184} \\
\hline & 4 stars & 1.5000 & & \\
\hline & 3 stars & 1.8571 & & \\
\hline \multirow{3}{*}{$\begin{array}{l}\text { Floating hotel change } \\
\text { management }\end{array}$} & 5 stars & 2.3000 & \multirow[t]{3}{*}{1.786} & \multirow[t]{3}{*}{0.184} \\
\hline & 4 stars & 1.5000 & & \\
\hline & 3 stars & 1.8571 & & \\
\hline
\end{tabular}

As shown in table 18, there are insignificant differences between the investigated hotels due to star classification regarding the reasons for returning to operation and tourism activities.

Table 19

The renovations' elements that will be emerged after a long time of stagnation

\begin{tabular}{|l|l|l|l|l|}
\hline No & Elements & Mean $^{*}$ & SD & Rank \\
\hline 1 & Attracting new market segments & 4.28 & 0.750 & 3 \\
\hline 2 & Designing new tourist programs & 3.00 & 1.590 & 6 \\
\hline 3 & Adapting new IT programs & 4.62 & 0.490 & 2 \\
\hline 4 & $\begin{array}{l}\text { Implementation of new Nile Cruise } \\
\text { maintenance and engineering programs }\end{array}$ & 4.65 & 0.481 & 1 \\
\hline 5 & $\begin{array}{l}\text { Conducting new training and skills } \\
\text { development programs }\end{array}$ & 4.20 & 0.759. & 4 \\
\hline 6 & $\begin{array}{l}\text { Apply for new friendly and green hotels } \\
\text { programs }\end{array}$ & 3.82 & 1.248 & 5 \\
\hline
\end{tabular}

*Mean of agreeing with renovations' elements, where: $1=$ strongly disagree; $2=$ disagree; $3=$ neutral; $4=$ agree; $5=$ strongly agree. $\mathrm{SD}=$ standard deviation

Table 19 indicated that the first element for renovating floating hotels after a long time of stagnation is the implementation of new Nile Cruise maintenance and engineering 
programs with a mean of (4.65) and std. deviation of (4810.). The second reason is adapting new IT programs with a mean of (4.62) and std. deviation of (0.490). Attracting new market segments came as a third reason with a mean of (4.28) and std. deviation of $(0.750)$. The fourth reason is conducting new training and skills development programs with mean of (4.20) and std. deviation of (0.759), in this regard respondents, suggested applying new HR Management Programs to guarantee employees' work rights. The fifth reason is applying for new friendly environment and green hotels programs with a mean of (3.82). The sixth reason is designing new tourist programs with mean of (3.00). Furthermore, respondents mentioned other elements such as signing protocols with reputable and trustworthy travel agents and tour operators, applying new health and safety programs, applying for new protective programs against the viruses and new anti-infection and sterilization system, signing contracts with auditing health and safety organizations through conducting training courses for health and safety, and awarding accreditation certificates, implement promotional activities through inviting the international cinemas and football celebrities for free visits to Luxor and Aswan, and offering complimentary accommodation in Nile cruises. This is plus shooting a camera for promotional video films. Then, publishing such videos through different worldwide satellite channels with different foreign languages.

These findings concur with the study of (Nguyen and Annaraud, 2018), they stated that the cruise field requires high caliber and skillful manpower that effectively influence guests' experience. As well Vafeidou (2019) stated that technology has created a radical change to the cruise industry that necessitates cruises to interact with the current technology elements.

Table 20

Independent samples T-test between the investigated floating hotels according to management type regarding Renovations' elements for floating hotels

\begin{tabular}{|l|c|c|c|c|}
\hline Reasons & Management type & Mean & $\mathrm{T}$ & Sig. (2-tailed) \\
\hline $\begin{array}{l}\text { Attracting new market } \\
\text { segments }\end{array}$ & Chain & 4.04 & -2.679 & $* 0.011$ \\
\cline { 2 - 5 } $\begin{array}{l}\text { Designing new tourist } \\
\text { programs }\end{array}$ & Chain & 2.54 & -2.340 & $* 0.025$ \\
\hline & Independent & 3.76 & & \\
\hline $\begin{array}{l}\text { Adapting new IT } \\
\text { programs }\end{array}$ & Chain & 4.59 & -0.586 & 0.562 \\
\hline $\begin{array}{l}\text { Implementation of new } \\
\text { Nile Cruise maintenance } \\
\text { and engineering programs }\end{array}$ & Chain & 4.69 & & \\
\hline $\begin{array}{l}\text { Conducting new training } \\
\text { and skills development } \\
\text { programs }\end{array}$ & Chain & 4.63 & -0.328 & 0.745 \\
\cline { 2 - 3 } $\begin{array}{l}\text { Apply for new friendly } \\
\text { and green hotels programs }\end{array}$ & Independent & 4.15 & & \\
\cline { 2 - 3 } & Chain & 3.90 & 0.273 & 0.787 \\
\hline
\end{tabular}

* Statistically-significant difference where $P$-value $<0.05$. 
Table 20 illustrates that an independent samples t-test was conducted to statistically examine the difference between means of these two groups. The results showed that 2 out of the 6 examined reasons have recorded statistically significant differences. In other words, these reasons are perceived to be more important among independent floating hotels than it is perceived by chain floating hotels. For example, "Attracting new market segments" was perceived to be a more influential reason among independent floating hotels $(\mathrm{M}=4.69$, $)$ than chain floating hotels $(\mathrm{M}=4.69)$, where $\mathrm{t}=$ 2.679, p-value $<0.05$. The other reason "Designing new tourist programs "is significantly higher among independent floating hotels $(\mathrm{M}=3.76$, ) than chain floating hotels $(\mathrm{M}=2.54)$, where $\mathrm{t}=--2.340$, $\mathrm{p}$-value $<0.05$

\section{Table 21}

Variance analysis between the investigated floating hotels according to star classification regarding renovations' elements for floating hotels using ANOVA test

\begin{tabular}{|c|c|c|c|c|}
\hline Reasons & Star classification & Mean & $\mathrm{F}$ & Sig. \\
\hline \multirow{3}{*}{$\begin{array}{l}\text { Attracting new market } \\
\text { segments and Aswan visits }\end{array}$} & 5 stars & 4.4500 & \multirow[t]{3}{*}{1.200} & \multirow[t]{3}{*}{0.314} \\
\hline & 4 stars & 4.0000 & & \\
\hline & 3 stars & 4.1429 & & \\
\hline \multirow{3}{*}{$\begin{array}{l}\text { Designing new tourist } \\
\text { programs }\end{array}$} & 5 stars & 3.4000 & \multirow[t]{3}{*}{1.525} & \multirow[t]{3}{*}{0.233} \\
\hline & 4 stars & 2.5000 & & \\
\hline & 3 stars & 2.4286 & & \\
\hline \multirow[t]{3}{*}{ Adapting new IT programs } & 5 stars & 4.6500 & \multirow[t]{3}{*}{0.387} & \multirow[t]{3}{*}{0.682} \\
\hline & 4 stars & 4.5000 & & \\
\hline & 3 stars & 4.7143 & & \\
\hline \multirow{3}{*}{$\begin{array}{l}\text { Implementation of new Nile } \\
\text { Cruise maintenance and } \\
\text { engineering programs }\end{array}$} & 5 stars & 4.8000 & \multirow[t]{3}{*}{2.248} & \multirow[t]{3}{*}{0.122} \\
\hline & 4 stars & 4.5000 & & \\
\hline & 3 stars & 4.4286 & & \\
\hline \multirow{3}{*}{$\begin{array}{l}\text { Conducting new training and } \\
\text { skills development programs }\end{array}$} & 5 stars & 4.3000 & \multirow[t]{3}{*}{0.456} & \multirow[t]{3}{*}{0.638} \\
\hline & 4 stars & 4.0000 & & \\
\hline & 3 stars & 4.1429 & & \\
\hline \multirow{3}{*}{$\begin{array}{l}\text { Apply for new friendly and } \\
\text { green hotels programs }\end{array}$} & 5 stars & 4.1500 & \multirow[t]{3}{*}{2.405} & \multirow[t]{3}{*}{0.106} \\
\hline & 4 stars & 3.7500 & & \\
\hline & 3 stars & 3.0000 & & \\
\hline
\end{tabular}

Table 21 Illustrates that there are insignificant differences between the investigated floating hotels due to star classification concerning renovations' elements for floating hotels.

\section{Table 22}

Operation stop date after emerging COVID 19

\begin{tabular}{|l|l|l|l|l|}
\hline & Month & Frequency & Percent \% & Rank \\
\hline \multirow{3}{*}{$\begin{array}{l}\text { When did you stop the } \\
\text { operation again } \\
\text { emerging COVID 19? }\end{array}$} & First of March & - & - & - \\
\cline { 2 - 5 } & Middle of March & 30 & 86 & 1 \\
\cline { 2 - 6 } & End of March & 5 & 14 & 2 \\
\cline { 2 - 5 } & During April & - & - & - \\
\hline \multicolumn{2}{|l}{ Total } & 35 & $100 \%$ & \\
\hline
\end{tabular}


The results table 22 showed that most of the investigated floating hotels (about $86 \%$ ) stopped the operation again after emerging COVID 19 in the middle of March, while only $14 \%$ stopped the operation at the end of March.

Table 23

COVID 19 infection cases in a floating hotel

\begin{tabular}{|l|l|l|l|l|}
\hline & \multicolumn{1}{|c|}{ Infection cases } & Frequency & Percent \% & Rank \\
\hline \multirow{2}{*}{$\begin{array}{l}\text { How many cases of } \\
\text { COVID 19 infection }\end{array}$} & Zero Infection & 16 & 45.7 & 1 \\
\cline { 2 - 5 } $\begin{array}{l}\text { appeared during this } \\
\text { period? }\end{array}$ & $1-25$ infection cases. & 14 & 40 & 2 \\
\cline { 2 - 5 } & $26-50$ infection cases. & 5 & 14.3 & 3 \\
\hline Total & More than 50 & - & - & - \\
\hline
\end{tabular}

Results clarified that $40 \%$ of the sample mentioned that the number of COVID 19 infection cases was between 1-25. This result is compatible with the findings from Gössling et al, (2020) study, which argued that cruise ships are often settings for outbreaks of infectious diseases because of their closed environment, contact between travelers from many countries, and crew transfers between ships"(Gössling et al, 2020). $45.7 \%$ of the sample mentioned that the number of COVID 19 cases was zero infection.

\section{Table 24}

The rate of fired employees after the COVID 19 crisis in floating hotels

\begin{tabular}{|l|l|l|l|l|}
\hline \multirow{2}{*}{$\begin{array}{l}\text { How many employees } \\
\text { have been fired after }\end{array}$} & Variables & Frequency & Percent \% & Rank \\
\cline { 2 - 5 } COVID 19 crisis? & $26-50 \%$ & 50 & 86 & 1 \\
\cline { 2 - 5 } & $51-75 \%$ & - & 14 & 2 \\
\cline { 2 - 5 } & More than 75\% & - & - & - \\
\hline \multicolumn{2}{|l}{ Total } & 35 & - & - \\
\hline
\end{tabular}

The tabulated data in table 24 declared that, $86 \%$ of investigated floating hotels mentioned that less than $25 \%$ of employees have been fired after COVID 19 crisis.

\section{Table 25}

The views and expectations of respondents about the quick recovery of operation and tourist activity when COVID 19 reaches to an end

\begin{tabular}{|c|c|c|c|c|}
\hline & Variables & Frequency & Percent $\%$ & Rank \\
\hline \multirow{2}{*}{$\begin{array}{l}\text { In your point of view, do you expect } \\
\text { that floating hotels operation and } \\
\text { tourist activity will recover quickly } \\
\text { when COVID } 19 \text { reaches to an end? } \\
\text { If yes, what are the forecasts that } \\
\text { prove your view? }\end{array}$} & Yes & 28 & 80 & 1 \\
\hline & No & 7 & 20 & 2 \\
\hline Total & & 35 & $100 \%$ & \\
\hline
\end{tabular}

Table 25 indicated that most of respondents representing $80 \%$ expect that floating hotels operation and tourist activity will recover quickly when COVID 19 reaches to an end due to the following forecasts stated by them: 
- Despite the COVID 19 crises, there is still demand from different international markets such as Spain, America, Russia, German, and Swiss.

- We received group reservations of 3 nights and 7 nights from international travel agents for next season till June 2021.

- We will not lose customers as travel agents do not cancel reservations, rather than postpone the reservation to the same tourist destination after the end of the crisis.

- Egypt possesses experts in Nile Cruise operation that have experience and capabilities of revitalizing tourism activities.

- The Ministry of Tourism is providing training courses to qualify new manpower to work in the Nile Cruises

- Increase the demand high - class market segmentations such as Japanese, America and British who can pay for the highest prices and represent the high rate of expenditure.

- Some tourists insist on repeating their visits to Egypt, despite crises, like the German tourist.

- Normally those tourism activities froze during the crises. However, when any crisis stops, the tourist activity returns and recover quicker than we all expect. We experienced that during the last 20 years, the increase in tourists' demand comes after the end of the crisis.

- While 20\% of respondents don't expect that floating hotels operation and tourist activity will recover quickly when COVID 19 reaches to an end due to the following reasons stated by them:

- COVID 19 is not a clear crisis as no one knows the date of its end. The period of the crisis may last for a very long time. Therefore, it is difficult to expect the time of tourist recovery.

- COVID 19 is an international epidemic disease that takes a long period of that and that leads to negative consequences as follows:

- Worldwide Economic crisis that minimizes the international demand, especially European demand on Egyptian Tourism

- Decrease in the tourists' incomes, and then, a decrease in the tourist expenditure

- Floating hotels' work stagnation with no movement and no operation result in many technical and maintenance problems that will take a lot of time for returning to its normal condition.

\section{Interview Analysis}

First: opportunities for Egyptian Nile Cruises' revitalization and development as well as returning to the normal tourist activities:

- Egypt in general, and Upper Egypt in specific, is a unique tourist destination and can never be substituted by another place especially for cultural tourism. Egypt 
possesses monuments and antiquities rarely found in other places in the world that return to the Ancient Egyptian civilization.

- The continuous direct and Indirect promotional and marketing activities of the Upper Egypt Nile Cruises.

- There are a lot of tourist attractions and sightseeing offered to tourists in Luxor and Aswan. Upper Egypt is not only famous with cultural and historical places but also with other tour sites such as Banana Island in Luxor, sound, and light, Kitchener's Island in Aswan, and other attractive places.

- The skills development training programs conducted to qualify new employees working in floating hotels.

- Long and professional experience in Upper Egypt in Cruise operation

- The financial support from the Ministry of Tourism to re-construct the cruise marines.

- Hosting some of the international events in Egypt such as cinema festivals, international conferences, and international sports' competitions.

- Prices' stability in most floating hotels.

- Upper Egypt is a huge market for Nile Cruises that organize amazing tour operation and deal with well-known international American travel agents and corporates such as the following: -

- Viking (Viking Osiris and Viking Ra'a)

- Gate 1

- Abercrombie \& Kent

- Oat \& Grand Circle

- Vintage

- Adventure by Disney

- National Geography

Second: Challenges threatening Nile courses' development:

- Leakage of qualified and well-trained employees.

- Limited maintenance and engineering renovation activities for the floating hotels.

- There are no pragmatic programs for Nile Cruises' activities' development.

- The weak infrastructure of the Cruise Marines as they are not equipped with fire protection, emergencies and professional sewage systems.

- Continuous Increase in licensing costs which has been doubled during the last 4 years.

- Closing the River Lock (Hawees) which delays the planned tours and then results in customers' dissatisfaction.

- Nile cruises are frequently exposed to crises which lead to blocking floating hotels' operation and freezing the Nile cruises' activities. COVID 19 crisis is the last and recent type of such crises. 
- Obligatory rules and regulations imposed by the Ministry of Tourism and other authorities regarding the health and safety, sailing and operations' certificates, adding to the high prices.

- The negative routine work of the government which hinders the development of the Nile Cruises' operation and activities.

- There is no coordination among the governmental authorities, the fact that causes overlap of responsibilities and discrepancies in decisions.

- The roads between Luxor and Aswan are unequipped and not suitable to host tourism activities.

- Seasonality of the tourism work operation in Luxor and Aswan, leads to unstable work-flow, high ratio of employees' turnover and unsustainability of development

- All-inclusive tour programs decreased the floating hotels' prices and consequently Egyptian Nile Cruises have been categorized as cheap tourist services, the fact that creates a negative image and undesirable reputation.

Third: Proposals for renovation and development of Egyptian Nile Cruises:

- Utilizing new tools of E-marketing for attracting new customers and consequently increasing demands.

- Caring about the needs, requirements, and desires of customers as the first priority of Nile Cruises' development.

- Providing further training programs to employees, focusing on recent technology, smart hotel applications and on-line services.

- Preparing and developing new marketing strategies and making some of the market researches for attracting new tourists' segments, focusing on prospective lucrative customers who can pay more such as Americans, Japanese and Germans.

- Building a new relationship with new corporates with new innovative tourist programs for increasing sales.

- Minimizing all-inclusive tour programs and concentrating on profitable tour programs.

- Recruiting new professional top management staff.

- Setting up quality standards of products and services like the ISO standards and standards of Operation (SOP).

- Developing professional auditing systems through signing protocols with auditing, inspection, and quality assurance companies to be certified in occupational health and safety, quality programs and other environment auditing and monitoring systems.

- Applying the sterilization, purification and anti-infection system imposed by the Ministry of Tourism and Antiquities for the health and safety certificates. 
- Developing complete maintenance and engineering programs for floating hotels as well as protective programs that make them alive for a longer time and survive within the sun heat and* climate changes' results.

- Setting up crises fund by both the government and employers to cover the financial deficiencies that usually occurred during crises.

\section{Conclusion}

Research findings are summarized in the following important key points:

- Firstly, the majority of sampled floating hotels, reaching $80 \%$, experienced work stagnation during the last 10 years due to sequential serious crises since 2011 that led to the absence of safety and security in some tourist places, as well as the leakage of qualified and well-trained manpower.

- The outbreak of COVID-19 pandemic in mid-March, 2020 recently added to reasons behind floating hotels stagnation.

- The main unpleasant impact of work stagnation reflected in the financial loss that reached $50-74 \%$ against the targeted profits of many floating hotels.

- Third, it has been declared that Nile Cruises' ships (Floating Hotels) are the first hotel establishments that undesirably influenced by COVID-19 outbreak owing to the locked environment of the cruise ship within a crowded space with guests' dealings and staff contacts.

- The main opportunity for the Egyptian Nile Cruises' revitalization is embodied in the fact that Egypt is a distinguished tourist destination that has no alternatives, especially for cultural tourism, supported with professional direct and indirect marketing activities and promotional support.

- The main challenges that represent critical obstacles against Egyptian Nile Cruises' revitalization are the leakage of qualified and well-trained staff as well as the exposure to sequences of crises from time to time especially after the sudden existence of COVID-19 contagion which surely will minimize both the tourism demand and supply in the future.

- It is proposed by respondents to sign contracts with new travel agents and reputable tour operators for attracting new market segmentations as well as employing modern E-marketing and promotional tools to increase tourism demand.

- Finally, it is recommended to sign protocols with Health and safety inspection companies for controlling the anti-virus protective procedures and other health and safety regulations imposed by the Ministry of Tourism and Antiquities. 


\section{Recommendations}

They are demonstrated in table 26

\section{Table 26}

Research Recommendations

\begin{tabular}{|c|c|c|}
\hline $\begin{array}{l}\text { The Assigned } \\
\text { Association }\end{array}$ & The Recommendation & Mechanism of Implementation \\
\hline \multirow[t]{5}{*}{$\begin{array}{l}\text { The Egyptian } \\
\text { Ministry of } \\
\text { Tourism and } \\
\text { Antiquities }\end{array}$} & $\begin{array}{l}\text { Controlling the inspection and } \\
\text { auditing processes related to the } \\
\text { newly imposed health and safety } \\
\text { regulations emerged after the } \\
\text { COVID-19 crises }\end{array}$ & $\begin{array}{l}\text { - Appointment of qualified and professional } \\
\text { health and safety inspectors } \\
\text { - Planning for inspection schedule to involve } \\
\text { all operating Floating Hotels } \\
\text { - Setting measurement criteria for inspection } \\
\text { - Setting the reporting and documentation } \\
\text { procedures for monitoring and evaluation } \\
\text { - Taking corrective actions towards } \\
\text { deviations and mistakes }\end{array}$ \\
\hline & $\begin{array}{l}\text { Facilitating the complicating } \\
\text { procedures of licenses' renewals, } \\
\text { within the constraints of } \\
\text { adapting legal processes and } \\
\text { conditions, especially after } \\
\text { tourism recovery from the } \\
\text { COVID-19 crisis. }\end{array}$ & $\begin{array}{l}\text { - Identifying the complicating procedures } \\
\text { - Consulting Floating Hotels owners and } \\
\text { managers for discussing the best solutions } \\
\text { and alternatives } \\
\text { - Reporting and publishing the modified } \\
\text { procedures as well as distributing to all } \\
\text { assigned entities }\end{array}$ \\
\hline & $\begin{array}{l}\text { Publishing an anti-infection } \\
\text { instructions' guide for } \\
\text { operational departments in hotel } \\
\text { associations including floating } \\
\text { hotels. }\end{array}$ & $\begin{array}{l}\text { - Selection of key experts and medical } \\
\text { consultants specialized in infectious } \\
\text { diseases } \\
\text { - Preparation of an anti-infection manual } \\
\text { guide focusing on protective instructions } \\
\text { and guidelines } \\
\text { - Printing the materials and distributing } \\
\text { among hotels, including floating hotels }\end{array}$ \\
\hline & $\begin{array}{l}\text { Establishing crisis management } \\
\text { committee with membership of } \\
\text { Egyptian hotel associations' } \\
\text { owners and managers, including } \\
\text { the floating hotels. }\end{array}$ & $\begin{array}{l}\text { - Holding meetings with all Nile Cruises' } \\
\text { stakeholders discussing the preparation of } \\
\text { crisis management strategies } \\
\text { - Setting the main objectives of the strategies } \\
\text { - Identifying the timeframe for strategies' } \\
\text { implementation } \\
\text { - Preparation of guideline materials about } \\
\text { previous crises with the solutions in order } \\
\text { to learn from past mistakes }\end{array}$ \\
\hline & $\begin{array}{l}\text { Forming a committee for } \\
\text { discussing all problems and } \\
\text { difficulties related to the } \\
\text { Egyptian Nile Cruises and } \\
\text { providing proposals for Nile }\end{array}$ & $\begin{array}{l}\text { - Identifying the main roles, duties, and } \\
\text { activities of this proposed committee that } \\
\text { should be legally published and approved. } \\
\text { - Issuing a legal decree making it controlled } \\
\text { and managed by the Egyptian Ministry of }\end{array}$ \\
\hline
\end{tabular}




\begin{tabular}{|c|c|c|}
\hline The Assigned & The Recommendation & Mechanism of Implementation \\
\hline & Cruises' revitalization. & $\begin{array}{l}\text { Tourism and Antiquities. } \\
\text { - Holding the committee regularly to involve } \\
\text { all Nile Cruises' stakeholders }\end{array}$ \\
\hline $\begin{array}{l}\text { The } \\
\text { Associations } \\
\text { Working in } \\
\text { Nile Cruises' } \\
\text { Management }\end{array}$ & $\begin{array}{l}\text { Employing smart technologies } \\
\text { and E-marketing as an } \\
\text { instrument for Egyptian Nile } \\
\text { Cruises' advertising and } \\
\text { promotion. }\end{array}$ & $\begin{array}{l}\text { - Exporting recent software programs and } \\
\text { applications used for E-marketing } \\
\text { - Providing training courses to employees } \\
\text { working in marketing and guest relation } \\
\text { departments } \\
\text { - Evaluating the effectiveness of smart } \\
\text { technologies on a regular basis }\end{array}$ \\
\hline & $\begin{array}{l}\text { Utilizing modern echo-systems } \\
\text { for Nile Cruises' sewage and } \\
\text { disposable programs }\end{array}$ & $\begin{array}{l}\text { - Contracting with echo-system and quality } \\
\text { management companies } \\
\text { - Hiring Green Hotel internal inspectors } \\
\text { - Setting documented procedures for regular } \\
\text { checking and inspection }\end{array}$ \\
\hline & $\begin{array}{l}\text { Preparing a marketing plan for } \\
\text { attracting new tourist } \\
\text { segmentation }\end{array}$ & $\begin{array}{l}\text { - Preparing new market survey to identify } \\
\text { the most profitable segmentation for Nile } \\
\text { Cruises } \\
\text { - Collecting all previous market studies done } \\
\text { by marketing department } \\
\text { - Distributing study results among marketing } \\
\text { staff for utilization } \\
\text { - Contracting with new travel agents dealing } \\
\text { with new market segmentations } \\
\text { - Study the profitability of dealing with new } \\
\text { segmentations and evaluating their benefits }\end{array}$ \\
\hline & $\begin{array}{l}\text { Qualifying new staff through } \\
\text { different skills development } \\
\text { training programs for replacing } \\
\text { the leaked ones who left their } \\
\text { jobs during the past crises }\end{array}$ & $\begin{array}{l}\text { - Preparing Training Need Analysis (TNA) } \\
\text { study } \\
\text { - Selecting the best candidate trainers for } \\
\text { training } \\
\text { - Implementing training and skills } \\
\text { development programs according to } \\
\text { international quality standards } \\
\text { - Evaluating efficiency of training }\end{array}$ \\
\hline & $\begin{array}{l}\text { Adapting modern quality } \\
\text { standards of operations' systems } \\
\text { that are applied internationally in } \\
\text { well-known cruise ships. } \\
\end{array}$ & $\begin{array}{l}\text { - Preparation of a benchmarking studies to } \\
\text { best practices of cruise ships in the world } \\
\text { - Editing and distributing results of the study } \\
\text { among all departments and assigned staff }\end{array}$ \\
\hline
\end{tabular}




\section{References}

- Alkan, G., Koraltürk, A. P. G., Öncü, A. P. G., \& Eroğlu Pektaş, C. K. P. (2015). Evaluation of Istanbul port in cruise tourism in terms of brand value. Management, 4(4), 276-285.

- Artal-Tur, A., Navarro-Azorín, J. M., \& Ramos-Parreño, J. M. (2019). Estimating the impact of cruise tourism through regional input-output tables. Anatolia, 30(2), 235245

- Baker, D. M. A., Stockton, S., Fürst, E., Oberhofer, P., Stöglehner, G., Dieplinger, M., \& Zagelmeyer, S. (2013). Caribbean cruise tourism: issues, challenges and sustainability. Studies of Organisational Management \& Sustainability, 1(2), 79-97.

- Chua, B. L., Lee, S., Kim, H. C., \& Han, H. (2019). Investigation of cruise vacationers' behavioral intention formation in the fast-growing cruise industry: The moderating impact of gender and age. Journal of Vacation Marketing, 25(1), 51-70.

- De Grosbois, D. (2016). Corporate social responsibility reporting in the cruise tourism industry: a performance evaluation using a new institutional theory based model. Journal of Sustainable Tourism, 24(2), 245-269.

- Delgado, R. (2017). The Cruise Industry: Destinations, Opportunities, Innovations, and Challenges. Journal of Advanced Management Science, 5.(5)

- Dipietro, R. B., \& Peterson, R. (2017). Exploring Cruise Experiences, Satisfaction, and Loyalty: The Case of Aruba as a Small-Island Tourism Economy. International Journal of Hospitality \& Tourism Administration, 18(1), 41-60.

- Domènech, A., Gutiérrez, A., \& Anton Clavé, S. (2019). Cruise Passengers' Spatial Behaviour and Expenditure Levels at Destination. Tourism Planning \& Development, 1-20.

- Dowling, R., and weeden ,C.,( 2017) Cruise Ship Tourism, CAB International, UK,

- Ege,I.(2020) The Impact of Coronavirus Disease (COVID-19) Pandemic on Cruise Industry : Case of Diamond Princess Cruise Ship. Mersin University Journal of Maritime Faculty (MEUJMAF), 2, (1), 32-37.

- Farag, N. M., \& El-Alfy, A. M. (2013). The role of Nile-islands in tourist attraction development. World Appl Sci J, 21(4), 578-592.

- Garay, L. A., Cànoves, G., \& Prat, J. M. (2014). Barcelona, a leader destination in cruise-passenger tourism: Keys, impacts and facts. International Journal of Tourism Sciences, 14(1), 23-49.

- Guardian (2020). Revealed: 100,000 crew never made it off cruise ships amid coronavirus crisis, available at: https://www.theguardian.com/environment/2020/apr/30/no-end-in-sight-100000-crew-oncruise-ships-stranded-at-sea-coronavirus (Accessed in 21 /7/2020). 
- Gössling, S., Scott, D., \& Hall, C. M. (2020). Pandemics, tourism and global change: a rapid assessment of COVID-19. Journal of Sustainable Tourism, 1-20.

- Gouveia, A. X., and Eusébio, C. (2019). Assessing the direct economic value of cruise tourism in a port of call: the case of Funchal on the island of Madeira. Tourism and Hospitality Research, 19(4), 422-438.

- Ruiz-Guerra, I., Molina-Moreno, V., Cortés-García, F. J., \& Núñez-Cacho, P. (2019). Prediction of the impact on air quality of the cities receiving cruise tourism: the case of the Port of Barcelona. Heliyon, 5.1-26 .(3)

- Han, H., Yu, J., Koo, B., \& Kim, W. (2019). Vacationers' norm-based behavior in developing environmentally sustainable cruise tourism. Journal of Quality Assurance in Hospitality \& Tourism, 20(1), 89-106.

- Han, H., Eom, T., Chung, H., Lee, S., Ryu, H. B., \& Kim, W. (2019). Passenger repurchase behaviours in the green cruise line context: Exploring the role of quality, image, and physical environment. Sustainability, 11.1-15.(7)

- Jones, P., Comfort, D., \& Hillier, D. (2016). European river cruising and sustainability. International Journal of Sales, Retailing and Marketing, 5(1), 61-71.

- Lester, S. E., White, C., Mayall, K., \& Walter, R. K. (2016). Environmental and economic implications of alternative cruise ship pathways in Bermuda. Ocean \& coastal management, 132, 70-79.

- Liu, X., \& Chang, Y.-C. (2020). An emergency responding mechanism for cruise epidemic prevention - taking COVID-19 as an example. Marine Policy, 119.

- Liu-Lastres, B., Schroeder, A., \& Pennington-Gray, L. (2019). Cruise Line Customers' Responses to Risk and Crisis Communication Messages: An Application of the Risk Perception Attitude Framework. Journal of Travel Research, 58(5), 849865.

- London, W. R., Moyle, B. D., \& Lohmann, G. (2017). Cruise infrastructure development in Auckland, New Zealand: a media discourse analysis (2008-2016). Asia Pacific Journal of Tourism Research, 22(6), 615-633.

- Lopes, M. J., \& Dredge, D. (2018). Cruise tourism shore excursions: Value for destinations?. Tourism Planning \& Development, 15(6), 633-652.

- Lyu, J., Hu, L., Hung, K., \& Mao, Z. (2017). Assessing servicescape of cruise tourism: The perception of Chinese tourists. International Journal of Contemporary Hospitality Management, 29(10), 2556-2572.

- McCarthy, J. (2018). Responsible cruise tourism and regeneration: the case of Nanaimo, British Columbia, Canada. International Planning Studies, 23(3), 225-238.

- Najafipour, A. A., Marzi, V., \& Foroozanfar, M. H. (2014). The Future of Cruise Ship Tourism Industry: the challenges of cruising market and operations management. Journal of Social Issues \& Humanities, 2(7), 213-224. 
- Navarro-Ruiz, S., Casado-Díaz, A. B., \& Ivars-Baidal, J. (2019). Cruise tourism: the role of shore excursions in the overcrowding of cities. International Journal of Tourism Cities.

- Nguyen,Y.,and Annaraud,K.,(2018). Evolution and Trends in the U.S. Cruise Industry, Global Review of Research in Tourism, Hospitality and Leisure Management, 4 (1), 559-576.

- Penco, L., Profumo, G., Remondino, M., \& Bruzzi, C. (2019). Critical events in the tourism industry: factors affecting the future intention to take a cruise. International Journal of Contemporary Hospitality Management.

- Pino, G., \& Peluso, A. M. (2018). The development of cruise tourism in emerging destinations: Evidence from Salento, Italy. Tourism and Hospitality Research, 18(1), 15-27.

- Polat, N. (2015). Technical innovations in cruise tourism and results of sustainability. Procedia-Social and Behavioral Sciences, 195, 438-445.

- Ponton, D., And Asero, V. (2018). Representing Global Cruise Tourism: A Paradox of Sustainability. Critical Approaches to Discourse Analysis Across Disciplines, 10.(1)

- Ružić, D., Bosnić, I., \& Kelić, I. (2018). Marketing communication in the river cruise industry. International journal of multidisciplinarity in business and scienc, 4(5), 6773.

- Salti, A., \& Mohamed, M. H. (2019). Developing the concept of an integrated emergency response system for the tourism industry: case study of the cruise ship industry, PhD Thesis., Bournemouth University ,(UK.

- Sharples, L. (2019). Research note: customer experience management in cruise preconsumption. International Journal of Culture, Tourism and Hospitality Research.

- Sun, X., Feng, X., \& Gauri, D. K. (2014). The cruise industry in China: Efforts, progress and challenges. International Journal of Hospitality Management, 42, 71-84.

- The Egyptian Hotel Guide (2015 - 2016), Egyptian Hotel Association, Egypt

- Vafeidou, M., (2019). Smart Cruise Ships; in what way Information and Communication Technologies are revolutionizing Technologies are revolutionizing, Master thesis, School of Economics, Business Administration and Legal Studies,International Hellenic University,Thessaloniki, Greece.

- Vayá, E., Garcia, J. R., Murillo, J., Romaní, J., \& Suriñach, J. (2018). Economic impact of cruise activity: the case of Barcelona. Journal of Travel \& Tourism Marketing, 35(4), 479-492.

- Wang, H. (Ed.). (2019). Report on the Development of Cruise Industry in China (2018). Springer. 
- Whyte, L. J., Packer, J., \& Ballantyne, R. (2018). Cruise destination attributes: measuring the relative importance of the onboard and onshore aspects of cruising. Tourism Recreation Research, 43(4), 470-482.

- Wondirad, A. (2019). Retracing the past, comprehending the present and contemplating the future of cruise tourism through a meta-analysis of journal publications. Marine Policy, 108, 103618.

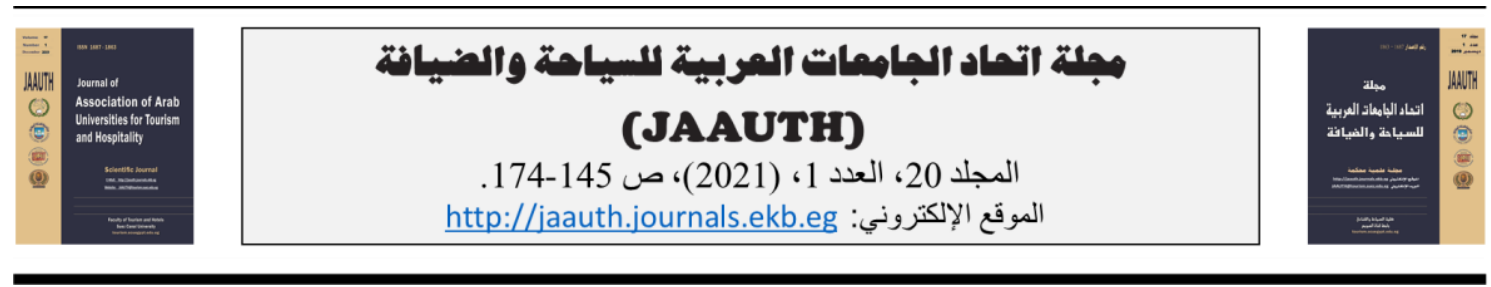

\section{الاتجاه نحو إحياء الرحلات السياحية النيلية في مصر : الفرص والتحديات}

$$
\begin{aligned}
& \text { خالد سليمان عبد الحليم } \\
& \text { نهلة محمد حلمي } \\
& \text { أستاذ مساعد، قسم الدراسات السياحية } \\
& \text { أستاذ مساعد، قسم إدارة الفنادق، } \\
& \text { كلية السياحة والفنادق، جامعة الأقصر. } \\
& \text { كلية السياحة والفنادق، جامعة بنى سويف. }
\end{aligned}
$$

الالبفn

ينظر إلى الرحلات المائية كإحدى الأنشطة السياحية الآخذة في النمو عالمياً ولذا

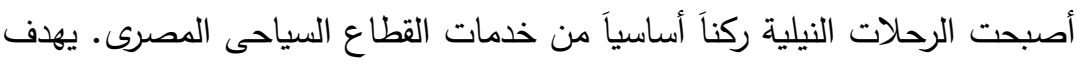
البحث إلى إعطاء صورة عامة وحديثة عن الرحلات النيلية فى مصر وإظهار

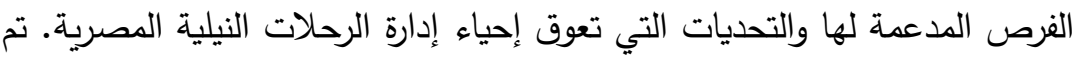

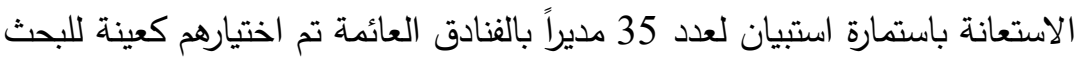

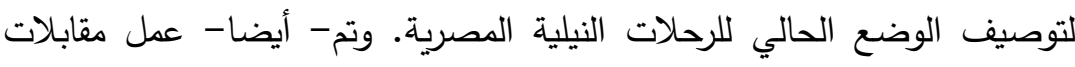

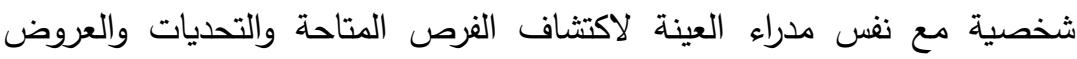

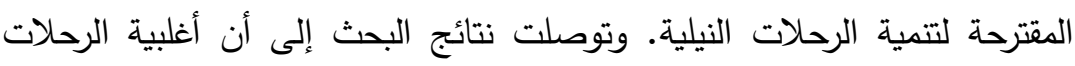

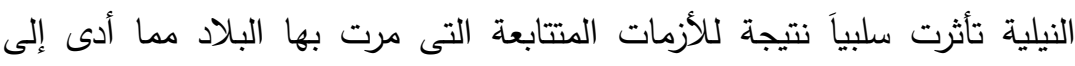


فيروس كورونا المستجد ويرجع ذلك إلى أن الفندق العائم هو أكثر المنشآت الفئنات الفندقية

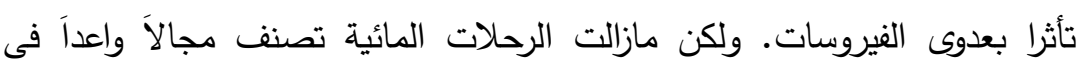

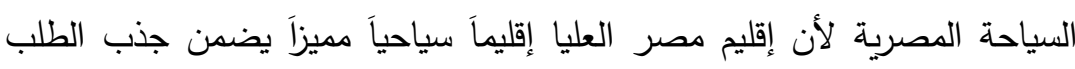

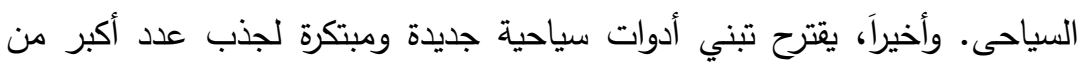


وتوكيد الجودة وضمان الصحة والأمان وإدارة الإجراءات الوقائية العائة والإحترازية.

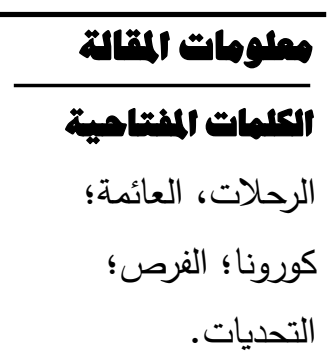

\section{(JAAUTH)}

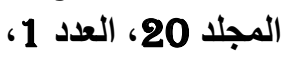

، (2021)

ص ص 174-145. 